\title{
The Effects of a Group Counseling Program on the Self-Esteem of Children from Multicultural Families
}

\author{
Hye-Ran Kim¹), Hyundong Son²)
}

\begin{abstract}
This study is aimed to develop a group counseling program to promote the self-esteem of children from multicultural families and test its effects. To this end, an 11-session program was developed based on the reviewed literature on self-esteem improvement programs. The program was characterized by activities designed to facilitate interactions among children and increase their participation, encourage them to have a positive viewpoint of a multicultural environment, and accumulate success experiences. The program was applied to five fifth-graders from multicultural families twice per week. Its effects were tested with the self-esteem inventory and investigator's observation on participants' behaviors in each session. Based on the results of the study, the developed group counseling program was effective in promoting the self-esteem of children from multicultural families. Also, it showed that the program could be used in lessons at schools where it was difficult to secure counseling hours with children.
\end{abstract}

Keywords: Children from Multicultural Families, Group Counseling Program, Self-Esteem, Group Counseling, Multicultural Families

\section{Introduction}

Korean society has become a multicultural society with increases in the number of international marriages and foreign workers. Under this social trend, the number of students from multicultural families is also increasing. Accordingly, the Ministry of Education has implemented various policies such as supporting basic education, consolidating education to understand multiculturalism, and supporting its adaptation in public education. However, the number of children of multicultural families still encounter various challenges. Children of

Received(June 22, 2020), Review Result(1st: August 14, 2020, 2nd: September 30, 2020), Accepted(October 28, 2020)

1) (Teacher) 61204 Dept. Education, Gwangju National Univ. of Education, 55 Pilmundaero, Pukgu, Gwangju, Korea

email: bluetreea@naver.com

2) (Professor, Corresponding Author) 61204 Dept. Education, Gwangju National Univ. of Education, 55 Pilmundaero, Pukgu, Gwangju, Korea

email: chamcoun@gnue.ac.kr

*This study is a revised and supplemented thesis for the first author's Master's degree (Gwangju National University of Education, 2019) 
multicultural families experience a delay in language development from infancy due to circumstances unconducive to learning Korean, which results in poor learning ability and comprehension[1], and they show low learning concentration and participation in learning due to their lack of Korean proficiency, which results in low learning achievements[2-5]. Furthermore, according to a survey of the actual status of 6,079 children of multicultural families by the Ministry of Gender Equality and Family[6], 5\% experienced school violence, and 9.4\% experienced discrimination throughout their lives. Factors leading to discrimination against children of multicultural families include external characteristics such as their appearance and poor Korean speaking skills, which distinguish them from Koreans, and they also suffer hardships due to cultural differences and social prejudices[7]. Children from such multicultural families have lower self-esteem than children from non-multicultural families[8], overall lower self-pride as a member of a multicultural family[6], and lower social and emotional competency than children from non-multicultural families due to difficulties learning the social and emotional skills inculcated in the home[9-10]. Moreover, they experience confusion in the process of forming their identities due to the education of mixed cultures at school and home[1].

Children of multicultural families experience a variety of difficulties. If the hardships they encounter are neglected, this will progress to serious social concerns in the future. Therefore, the central government, local governments, and youth facilities have competitively developed and operate programs for children of multicultural families. However, a majority of these programs are one-time programs based on a simple experience or a cultural experience[11] or services that only provide group education, failing to adequately provide services appropriate to an individual's needs[12]. With approximately half of the generation of children of multicultural families entering school age, it is necessary to identify their desires and needs for support and to provide support to children of multicultural families so that they can grow up to be healthy members of our society[3].

Several studies have emphasized self-esteem as a factor supporting and protecting the children of multicultural families[13-15]. Self-esteem is the mindset of believing oneself valuable and deserving of love, and individuals with high self-esteem consider themselves valuable and competent, form good relationships with others, take on challenges, and are good at overcoming stress and adversity[16]. Children with high self-esteem perceive their subjective well-being to be high[17], and a higher sense of self-esteem in children of multicultural families has further positive impacts on their adaptation to society[18]. Therefore, the sense of self-esteem, a factor that supports and protects them, must be improved in children of 
multicultural families who face various hardships for them to grow into healthy members of society. Thus the development of practical programs that can assist in enhancing self-esteem is needed.

The majority of self-esteem promotion programs targeted children in general or children receiving educational welfare[19-23], thus, do not reflect the characteristics or needs of children of multicultural families. Consequently, there were difficulties in applying such programs to children of multicultural families. The majority of existing programs for multicultural children programs that focus on the socialization process of children of multicultural families[24-27] and the development of programs related to self-esteem for multicultural children remain inadequate.

Therefore, this study is aimed to develop a group counseling program to promote the self-esteem of children of multicultural families and to verify the effectiveness of the program in children of multicultural families. The research questions are as follows. First, what should constitute a group counseling program to promote the self-esteem of children of multicultural families? Second, how effective is a group counseling program in promoting the self-esteem of children of multicultural families?

\section{Methods}

\subsection{Development of the Group Program}

To develop a program systematically, the process of goal setting, program composition, preliminary research, and program implementation and improvement were set following the program development model of Kim[28]. First, the theoretical background, literature, and previous studies were reviewed in the goal-setting stage to develop a group counseling program to promote the self-esteem of children of multicultural families. A needs analysis was conducted with 42 individuals, including 20 teachers and 22 children of multicultural families, and the results were analyzed. In the program composition stage, previous research on existing group counseling programs to promote self-esteem[16][19-24], previous research on group counseling programs for children of multicultural families[25][27][29-31], and previous research on group counseling programs to promote self-esteem in children of multicultural families [26][32-36] were analyzed. This was followed by short-listing of activities to be included in the program based on the needs survey, theory reviews, and analysis of the previous studies. The short-listed activities were arranged and intervention strategies were selected to design a preliminary program. In particular, the programs comprised a variety of activities to promote 
the active participation of children, activities reflecting the characteristics of children of multicultural families, activities to help children of multicultural families understand their two cultures and form a positive perspective on both, activities to identify their strengths as a multicultural person and respect themselves, and activities to allow multicultural children to experience success. When selecting the program content, the activities that had been indicated as highly preferred by teachers and children in the needs survey were included.

\subsection{Participants}

This program was conducted in one of the classes of the 5th grade of A Elementary School located in G-gun, Jeollabuk-do (a total of nine students, including seven children of multicultural families and two children from non-multicultural families). The researchers chose the 5th graders as the research subjects for they are able to communicate effortlessly without difficulties in listening, speaking, reading, and writing. The subjects of this study were three of the children of multicultural families, who provided consent from both themselves and their parents.

[Table 1] Characteristics of Each Program Participant

\begin{tabular}{|c|c|c|c|}
\hline Student & sender & Family background & Personality and behavioral \\
\hline $\mathrm{A}$ & Male & $\begin{array}{l}\text { Mother's country of origin: Vietnam } \\
\text {. Close relationship with parents } \\
\text { - Does not have many others to speak } \\
\text { with as he is an only child }\end{array}$ & $\begin{array}{l}\text { Likes to talk with other people } \\
\text { Easily feels hurt and remembers the scars }\end{array}$ \\
\hline $\mathrm{C}$ & Male & $\begin{array}{l}\text { Mother's country of origin: Vietnam } \\
\text { Has affection for his parents and a } \\
\text { good relationship with his parents } \\
\text { His mother is interested in their } \\
\text { children's school life and his older } \\
\text { brother takes good care of him. }\end{array}$ & $\begin{array}{l}\text { - Is reluctant to express his thoughts or } \\
\text { feelings and likes quietness } \\
\text {. Sometimes cries quietly alone when } \\
\text { offended } \\
\text { - Is cautious about everything }\end{array}$ \\
\hline $\bar{D}$ & Female & $\begin{array}{l}\text { - Mother's country of origin: Vietnam } \\
\text { Says dad treats her well } \\
\text { - Tends to tell mother or sister about } \\
\text { troubles } \\
\text { - Mother actively participates in school } \\
\text { events }\end{array}$ & $\begin{array}{l}\text { Enjoys and is competent in leading } \\
\text { others } \\
\cdot \text { Is often stressed from friendships and } \\
\text { feels anxious } \\
\text { - Has high motivation to learn }\end{array}$ \\
\hline
\end{tabular}

\subsection{Tools}

The self-esteem test tool used in this study was the scale reconstructed by Choi and Jeon[37] 
based on the self-esteem scale of Coopersmith[38]. This test tool consists of a total of 32 questions in four sub-areas: general self-esteem (6 questions), social self-esteem (9 questions), family self-esteem (9 questions), and academic self-esteem (8 questions), all scored on a 5-point Likert scale.

\subsection{Procedures}

The program was conducted for a total of 11 sessions twice a week for approximately 6 weeks, from April 17 to May 22, 2019, and the duration of each session was 40 minutes. The program was conducted by the principal investigator. A pre-test for self-esteem was conducted before the self-esteem promotion program, and a post-test followed the completion of the program. During the process, the behaviors and works of children were observed and recorded on an observation sheet, and a program satisfaction test was conducted at the end of each session.

\subsection{Data Processing and Analysis}

In this study, the self-esteem promotion group counseling program was applied to children of multicultural families and was analyzed as follows to investigate changes in self-esteem. First, a self-esteem test was conducted before and after the self-esteem promotion group counseling program, and the results were analyzed. Second, the results of the observed behavior of children who participated in each session were analyzed. Changes in children's behavior were analyzed based on the observation sheets for children's behavior during the program and the works created by the children during the session.

\section{Results}

\subsection{Self-esteem Promotion Program for Children of Multicultural Families}

In the preliminary research stage, the researcher conducted preliminary programs in the area of self-awareness and understanding of peer relations and acceptance for children of multicultural families in the 6th grade. The preliminary programs were applied in two sessions to the same cohort, and the process was followed by modification and supplementation of the programs. Also, four expert teachers who had the experience of developing and conducting a self-esteem improvement program participated in consulting process to evaluate the validity of the program. In the final stage, the consultation was provided by one professor who is an expert 
in the theory of this field. After referring to expert evaluations and expert suggestions, we opted to develop an activity that encouraged finding happy experiences with family beyond the restrictions of experiences within the multicultural family: experiences visiting their parents' countries. The activity was modified to encourage children to explore their experiences in diverse ways, and the activity to build rapport was modified as a cooperation game. Therefore, the self-esteem promotion program for children of multicultural families was finalized by revising and supplementing the preliminary research results, content validity evaluation, and suggestions of experts (see [Table 2]).

[Table 2] Self-esteem Promotion Program for Children of Multicultural Families

\begin{tabular}{|c|c|c|c|c|c|}
\hline Area & Factor & $\begin{array}{c}\text { Sess } \\
\text { ion }\end{array}$ & Title & Goal & Activity \\
\hline \multirow[t]{2}{*}{$\begin{array}{l}\text { Building } \\
\text { Relation- } \\
\text { ships }\end{array}$} & $\begin{array}{l}\text { Introducing } \\
\text { oneself }\end{array}$ & 1 & $\begin{array}{l}\text { Introducing } \\
\text { myself }\end{array}$ & $\begin{array}{l}\text { - Understanding the } \\
\text { objective and operation } \\
\text { method of the program } \\
\text { - Recognizing members of } \\
\text { the group through } \\
\text { self-introduction }\end{array}$ & $\begin{array}{l}\cdot \text { Program introduction } \\
\cdot \text { Setting rules } \\
\cdot \text { - Making nickname badge } \\
\text { - Presenting nicknames }\end{array}$ \\
\hline & $\begin{array}{l}\text { Building } \\
\text { rapport }\end{array}$ & 2 & $\begin{array}{l}\text { I want to be } \\
\text { together }\end{array}$ & $\begin{array}{l}\text { - Easing the tension } \\
\text { - Sharing positive feelings } \\
\text { between members of the } \\
\text { group }\end{array}$ & $\begin{array}{l}\text { - Cooperatively moving the cup } \\
\text { - Completing drawing of one's } \\
\text { own face after completing the } \\
\text { mission to receive an autograph } \\
\text { from a friend }\end{array}$ \\
\hline \multirow[t]{3}{*}{$\begin{array}{l}\text { Self- } \\
\text { Acceptance }\end{array}$} & \multirow[t]{2}{*}{$\begin{array}{l}\text { Recognition } \\
\text { and } \\
\text { understan- } \\
\text { ding } \\
\text { of } \\
\text { oneself }\end{array}$} & 3 & $\begin{array}{l}\text { Figuring out } \\
\text { what I want }\end{array}$ & $\begin{array}{l}\text { Discovering the desires } \\
\text { of the participants }\end{array}$ & $\begin{array}{l}\text { - Writing or creating a collage from } \\
\text { magazines after thinking about } \\
\text { what they want to do, what they } \\
\text { want, what they want to possess, } \\
\text { things they want to hear, on the } \\
\text { picture of body. }\end{array}$ \\
\hline & & 4 & $\begin{array}{l}\text { Finding my } \\
\text { own treasure }\end{array}$ & $\begin{array}{l}\text { - Discovering the strengths } \\
\text { (including strengths as a } \\
\text { multicultural person) } \\
\text { and advantages of the } \\
\text { participant } \\
\text { - Discovering the good } \\
\text { points in the strengths } \\
\text { of others }\end{array}$ & $\begin{array}{l}\text { Participants write what they } \\
\text { consider to be their own } \\
\text { strengths and the strengths } \\
\text { others see in them on sticky } \\
\text { notes } \\
\text { - Identifying and sharing the } \\
\text { strengths they want to acquire } \\
\text { from others' lists }\end{array}$ \\
\hline & $\begin{array}{l}\text { Accepting } \\
\text { oneself }\end{array}$ & 5 & $\begin{array}{l}\text { Find your } \\
\text { image }\end{array}$ & $\begin{array}{l}\text { - Discovering a positive } \\
\text { image of self from } \\
\text { relationships } \\
\text { - Accepting their own } \\
\text { image positively }\end{array}$ & $\begin{array}{l}\text { - Writing words that made } \\
\text { participants feel good and the } \\
\text { compliments they have heard } \\
\text { from others } \\
\text { - Expressing the feelings } \\
\text { participants felt when they } \\
\text { received positive feedback }\end{array}$ \\
\hline
\end{tabular}


Vol.6, No.11, November 30 (2020), pp.159-172

http://dx.doi.org/10.47116/apjcri.2020.11.14

\begin{tabular}{|c|c|c|c|c|c|}
\hline \multirow[t]{3}{*}{$\begin{array}{l}\text { Accepting } \\
\text { others }\end{array}$} & \multirow{2}{*}{$\begin{array}{l}\text { Understan- } \\
\text { ding } \\
\text { and } \\
\text { accepting } \\
\text { family } \\
\text { relationships }\end{array}$} & 6 & $\begin{array}{l}\text { Family of } \\
\text { diversity }\end{array}$ & $\begin{array}{l}\cdot \text { Recognizing their } \\
\text { family relationship }\end{array}$ & $\begin{array}{l}\text { - Expressing themselves with } \\
\text { animal families made of clay } \\
\text { - Introducing an animal family } \\
\text { made of clay }\end{array}$ \\
\hline & & 7 & $\begin{array}{l}\text { We are } \\
\text { happier } \\
\text { because we } \\
\text { are different }\end{array}$ & $\begin{array}{l}\text { Exploring enjoyable } \\
\text { experiences with family } \\
\text { (such as visiting parents' } \\
\text { countries) }\end{array}$ & $\begin{array}{l}\text { - Making an album of fun } \\
\text { experiences with family (such as } \\
\text { visiting parents' countries) } \\
\text { - Sharing their feelings }\end{array}$ \\
\hline & $\begin{array}{l}\text { Understan- } \\
\text { ding and } \\
\text { accepting } \\
\text { peer } \\
\text { relationships }\end{array}$ & 8 & $\begin{array}{l}\text { Fun with } \\
\text { friends }\end{array}$ & $\begin{array}{l}\text { Exploring experiences } \\
\text { participants enjoyed } \\
\text { with friends }\end{array}$ & $\begin{array}{l}\text { - Creating a fun experience with } \\
\text { friends as a stop-action quiz } \\
\text { - Talking about the experience } \\
\text { through an interview }\end{array}$ \\
\hline \multirow[t]{2}{*}{$\begin{array}{l}\text { Sense of } \\
\text { competenc } \\
\mathrm{y} \text { and } \\
\text { achievement }\end{array}$} & $\begin{array}{l}\text { Cooperation } \\
\text { and } \\
\text { problem } \\
\text { solving }\end{array}$ & 9 & $\begin{array}{l}\text { Together, it is } \\
\text { possible }\end{array}$ & $\begin{array}{l}\text { Developing a spirit of } \\
\text { cooperation and } \\
\text { problem-solving skills } \\
\text { through cooperative } \\
\text { activities }\end{array}$ & $\begin{array}{l}\text { Playing five types of cooperative } \\
\text { games (indoor basketball, } \\
\text { badminton using rugs, word } \\
\text { chain using body, cooperative } \\
\text { ping pong ball transfer, picture } \\
\text { quiz relay) }\end{array}$ \\
\hline & $\begin{array}{l}\text { Sense of } \\
\text { achievement }\end{array}$ & 10 & $\begin{array}{l}\text { We can do it } \\
\text { if we do it } \\
\text { together }\end{array}$ & $\begin{array}{l}\text { Experiencing a sense of } \\
\text { trust and achievement } \\
\text { through cooperative } \\
\text { activities }\end{array}$ & $\begin{array}{l}\text { - Creating picture in collaboration } \\
\text { - Sharing the experiences of being } \\
\text { together }\end{array}$ \\
\hline Wrap-up & $\begin{array}{l}\text { Self- } \\
\text { evaluation } \\
\text { and } \\
\text { acceptance }\end{array}$ & 11 & $\begin{array}{l}\text { Growing } \\
\text { one more } \\
\text { step }\end{array}$ & $\begin{array}{l}\cdot \text { Recognizing positive } \\
\text { changes in self } \\
\cdot \text { Encourage positive } \\
\text { changes in self }\end{array}$ & $\begin{array}{l}\text { - Giving points to the changed self } \\
\text { - Writing a greeting card to self } \\
\text { - Writing a congratulatory message } \\
\text { to a friend and sending it as a } \\
\text { gift as a paper airplane }\end{array}$ \\
\hline
\end{tabular}

\subsection{Self-esteem Inventory}

In terms of the changes in the self-esteem score in children participating in this study, the self-esteem score of Participant A increased the most (an increase of 18 points), while the scores also increased of $\mathrm{C}$ (by 9 points) and D (by 4 points). This results indicate that their self-esteem increased through the program.

[Table 3] The Scores of Self-esteem Pre and Post Test

\begin{tabular}{cccc}
\hline students & pre-test & post-test & score change \\
\hline A & 95 & 113 & +18 \\
\hline C & 96 & 105 & +9 \\
\hline D & 100 & 104 & +4
\end{tabular}




\subsection{Results of Observing the Behavior}

\subsubsection{Analysis of Activities by Session for Participant A}

In the first session, A thought about his nickname and asked the group members to help to choose it. However, A showed relatively active behaviors and listened to presentations from other group members. During the fourth session, which was based on activities to find one's own strengths, A, who often went to Vietnam, spoke about his comfort when he went to Vietnam as an advantage of being a multicultural person. He was observed to recognize his strengths as a multicultural person. In the sixth session, which involved activity to express their families with clay, A was the only participant to express the whole family together. The family with three members were watching television together. His mother was a rabbit because she tended to finish tasks quickly. His father was an elephant because he was tall, big, and slow in motion. He expressed himself as a fish because he wanted to be good at swimming like his mother. He smiled happily throughout his explanation of his family, and he demonstrated an understanding of the traits of his family members. In the seventh session, A drew an image of his family together on a flight to Vietnam as a memory with his family. He spoke of things that happened in Vietnam, and his friends asked questions to satisfy their curiosity. He was excited to speak about Vietnam with his friends as he shared about the food he ate, the places he visited, and the things he experienced in Vietnam. When he was asked to speak about how he felt, he said it was good to be able to recall the joyful moments he had had with his family. This showed the positive recognition A had of his family. In the ninth session, A demonstrated a wish to be with and wait for a friend who could not score in the indoor shoe-kick-off game. He also actively suggested his strategy to his friends to make the game successful. In the 11th session, A was sad when the program host announced that it was the last session. He seriously wrote this during the activity of writing a letter to himself. Upon receiving a paper airplane with a friend's message, he read the message in a voice loud enough for all of his friends to hear, and he appeared to be happy.

\subsubsection{Analysis of Activities by Session for Participant C}

C, who usually thinks for a long time and is cautious, was unable to choose a nickname during the first session of the nickname building activity. Other friends made suggestions as they spoke on several things, but C refused their suggestions, possibly out of dissatisfaction. Moreover, he wrote his name in pencil without decorations on his nickname badge. During the 
second session, $\mathrm{C}$ did not fill in more than half of the space provided to complete the task within the time limit, but he liked the pictures drawn by his friends. In the third session, an activity to express one's own desire, $\mathrm{C}$ expressed the desire to live quietly. C, who enjoys silence and quiet, was under stress from the active and talkative group members in the classroom. However, he tended to not express his stress, and only indirectly expressed his desire for the classroom to be quiet through this activity. In the fourth session, on finding one's own strengths, C claimed to be healthy as his strength. In the fifth session, on the words that made one feel good, C said he feels grateful when his other brother says, "I'll teach you." In the sixth session, with the activity to express his family through clay, other members of the group showed themselves to relate to C's work. Following the response from other members, C made his presentation with a smile. In the seventh session, to depict a joyful experience with family, C drew his visit to his uncle's wedding in Vietnam. During his presentation, he shared that it was fun and that he wants to visit again, and group members shared various topics related to Vietnam, including the experience and the food. C was found quietly crying after the program. When asked why he was crying, he said he remembered his great-grandmother in Vietnam, who had passed away. C, who did not normally express himself, established a positive image of his family as he spoke extensively about Vietnam. In the ninth session, C, who did not actively participate in previous activities, was observed to be proactively involved in the cooperation game. In the tenth session, 'draw together ', C showed his usual self of listening and accepting other group members' opinions without proactively sharing his own opinions, and fulfilled his duty. He felt proud when the picture drawn in collaboration was complete and displayed the picture with his friends and teacher in the classroom.

\subsubsection{Analysis of Activities by Session for Participant D}

D, who enjoys decorating, enjoyed the activity of creating nicknames and decorating her badge. She also enjoyed being called by her nickname. In the second session, she was observed to joyfully participate in games with friends and ease her tension. In the third session, on expressing what they want, she outlined what she wants to hear and possess. However, she wrote that the things in her heart are secret and that she was hesitant to share further. In the fourth session, D presented her favorite strength as a multicultural person as being able to eat food from her country. D was observed to change her recognition of having two cultures as her strength through this activity. In the fifth session, on understanding their desires, D expressed her desires by sticking various sticky notes on the provided drawing paper. Regarding the feelings she felt when her friends asked to do things together, she expressed the 
most, seven. In her presentation, D said that she thinks there is much she wants to do and possess. In the seventh session, to express the joy of being with her family as an album, D showed proactive engagement by drawing two. One album depicted her family watching a movie together, the other playing board games, and she presented both albums. In sharing her experiences with her friend during the eighth session, D told about cooking with friends at her home. Her face was radiantly bright when she shared this experience as a quiz. D enjoyed and was proactive in the cooperation game during the ninth session. She proactively shared her opinions during strategy time, and she appeared to be delighted with her group members when they were successful in the game mission. In the tenth session, which required participants to draw together, D suggested drawing an apple tree. All members of the group agreed with her suggestion, which appeared to please her. D experienced problem-solving by cooperating with other group members. In the 11th session, D chose "depicting a joyous memory with her family" as her most memorable activity.

\section{Discussion and Conclusion}

This study was conducted to develop a group counseling program to promote self-esteem in children of multicultural families and to verify the effects of the program in enhancing their self-esteem. The discussion of the program design and the verification of its effectiveness is as follows.

First, regarding the program design, the developed program comprised 11 sessions involving the inclusion of various activities to elevate the participation of children of multicultural families including interviewing through a stop-action quiz with friends, expressing their family as animals in clay, playing games with friends, and drawing pictures cooperatively. This program was developed based on a previous study[39], which stated that children will actively participate if an appropriate atmosphere is created by diversifying the format of counseling. Second, the contents of this program included activities that allow children of multicultural families to positively recognize their strengths and biculturalism. This is in accordance with previous studies[14][40-42] that suggested that children of multicultural families should recognize their potential and positively develop their bicultural identity. The third characteristic was the inclusion of activities to provide an experience of positive relationships with others and to accumulate their experience of success. Such contents are consistent with the comments of Jeong[43], who listed the important factors influencing the formation and development of self-esteem as experiences of success and failure, relationships with important individuals, and 
evaluation and feedback from the individuals.

Second, the group counseling program was effective in promoting the self-esteem of children of multicultural families. The results of the self-esteem test and observation of children's behavior showed positive effects. During the course of the group counseling program, A formed a positive image of others, such as family and friends, in the process of exploring enjoyable experiences with family and friends. After the end of the program, he maintained a positive image of his family, confessing that he had not thought of such memories despite the numerous enjoyable memories he had with his family. $\mathrm{C}$ was also identified as having formed a positive image of his family when he confessed how he came to think deeply about the immense efforts his parents were undertaking and how he is attempting to help his parents. D built recognition of herself in the process of understanding her own desires and strength. She confessed that she came to think about numerous things regarding her mother's country including food and being able to travel for holidays, which showed her positive recognition of having two cultures.

The program developed in this study is expected to help increase the self-esteem of children of multicultural families and may be applied in a reconstructed format in small rural school classrooms, where children of multicultural families make up a significant proportion. However, this study has limitations, and suggestions based on the limitations are as follows. First, distrust and fixed rejection despite explanations regarding the self-esteem promotion counseling program were identified in parents of children of multicultural families in the process of obtaining research consent for this program. It is challenging to proceed with a program for children of multicultural families without the parents' consent, no matter how outstanding it may be. Therefore, studies to identify how parents of children of multicultural families perceive their children's education and participation in various programs and to determine the factors that cause hesitation in permitting their children to participate in such programs are needed. Second, this study targeted students from small rural schools, and the participating children were familiar with each other, as they had been members of the same cohort for more than five years. Therefore, the initial stages of the program proceeded effortlessly, and some students were comfortable with opening themselves to the others. However, some students did not do so due out of excessive familiarity with each other and having to continue to see them in the same class in the future. Therefore, studies of measures to reduce this burden are required in the future. 


\section{References}

[1] M. S. Choi, S. J. Kim, Tasks for moral education to establish self-identity of children in multicultural families, Journal of Ethics Education Studies, (2009), No.19, pp.91-118, UCI: G704-001561.2009..19.002

[2] Y. N. Yoon, A study on the current Status of 'Korean for learning' of multicultural students in elementary school and support methodology for It, Seoul National University of Education, Master's thesis, (2010)

[3] Y. W. Lee, Research analysis on language intervention studies for young children at-risk for language delays or learning disabilities from low-income and multicultural families, International Journal of Child Warfare Promotion and Management, (2018), Vol.2, No.2, pp.113-118.

[4] H. W. Jung, S. G. Park, J. R. Cho, A study on the literacy of multicultural family children with underachievement and cognitive-linguistic variables using the Korean Test of Literacy Diagnosis, Asia-pacific Journal of Convergent Research Interchange, (2019), Vol.5, No.3, pp.41-51, DOI: 10.21742/apjcri.2019.09.05

[5] Y. W. Lee, S. H. Lee, A study on teachers' perceptions of the developmental characteristics and educational supports for at-risk young children from multicultural families in South Korea, International Journal of Child Warfare Promotion and Management, (2018), Vol.2, No.2, pp.1-6, DOI: 10.21742/ijcwpm.2018.2.2.01

[6] 2015' An investigation on multicultural families in Korea, Ministry of Gender Equality and Family, (2016)

[7] Y. D. Cho, H. W. Yun, S. C. Park, Survey on the status of children's education in multicultural families, Ministry of Education and Human Resources Development, (2006)

[8] A. Y. Kim, S. I. Kim, Comparisons of psychological factors related to school adjustment between children from international marriage families and from general families, Korean Journal of Educational Psychology, (2011), Vol.25, No.4, pp.853-873, UCI: G704-000199.2011.25.4.004

[9] S. Y. Byun, K. W. Son, A Case Study of Children from Multicultural Family and It' Implication to Multicultural Virtue Research, Journal of Ethics Education Studies, (2011), No.26, pp.137-166, UCI: G704-001561.2011..26.006

[10] H. W. Jung, S. G. Park, J. R. Cho, A study on parenting styles of multicultural mothers, International Journal of Child Warfare Promotion and Management, (2018), Vol.2, No.2, pp.31-36, DOI:10.21742/ijcwpm.2018.2.2.06

[11] H. J. Kim, J. Yoo, A Study on the present condition of operating multicultural youth programs, Youth Facility and Environment, (2009), Vol.7, No.4, pp.17-32, UCI: G704-001838.2009.7.4.003

[12] M. J. Yang, H. Y. Gao, D. H. Lee, Y. H. Kim, Development of multicultural youth counseling manual, Korea Youth Counseling Institute, (2011)

[13] Y. H. Lee, A Study on an Effect of Attachment, Self-Esteem and social support to raise multicultural children's adaptation for school -focused on comparison with children in general families-, Korea National University, Master's thesis, (2009)

[14] K. S. Kim, T. H. Jung, Directions and tasks of school counseling for multicultural family students, Korean Journal of Elementary Education, (2010), Vol.20, No.2, pp.197-213, DOI: 10.20972/kjee.20.2.201001.197 
[15] M. H. Hwang, H. S. Ha, J. H. Kang, T. C. Yeo, Social development of multicultural children, The Korean Journal of Elementary Counseling, (2014), Vol.13, No.1, pp.71-96, UCI: G704-SER000003102.2014.13.1.008

[16] E. S. Kim, H. D. Son, Self-esteem program: Principles and practice, Hakjisa, (2015)

[17] H. J. Suh, S. H. Rho, The structural equation modeling of elementary school students' self-esteem, subjective happiness, and school adjustment, Journal of Parent Education, (2018), Vol.10, No.4, pp.55-70.

[18] K. S. Lee, The Influence of Self-Esteem of Multicultural Family's Children on Social Adjustment, Theory and Research in Citizenship Education, (2012), Vol.44, No.1, pp.91-107, DOI: 10.35557/trce.44.1.201203.004

[19] S. H. Park, The effects of the self-esteem enhancement program applied to the unit of a class on the self-esteem of elementary school students, Kyungpook National University, Master's thesis, (2010)

[20] B. Y. Kwon, The effect of the self-esteem improvement program on elementary school students self-esteem and academic achievement, Hannam University, Master's thesis, (2011)

[21] J. S. Lim, The effect of self-esteem promotion group counseling on the improvement of self-esteem of elementary school students, Hankuk University of Foreign Studies, Master's thesis, (2011)

[22] H. S. Min, Study on the effect of positive self-esteem improvement program on self-worth of elementary students, Wooksuk University, Master's thesis, (2015)

[23] Y. H. Hwong, Study on the effectiveness of self-esteem improvement program to personal relation and self-concept -focused on education welfare priority support programs children-, Dongguk University, Master's thesis, (2016)

[24] E. S. Kim, H. D. Son, M. O. Choi, B. M. Jeong, Development of a smartphone overdependence prevention group program in adolescents, Asia-pacific Journal of Convergent Research Interchange, (2019), Vol.5, No.4, pp.123-137, DOI: 10.21742/apjcri.2019.12.13

[25] S. B. Lee, The development of group counseling program to improve sociality of multicultural family elementary school children in lower grades, Korea National University of Education, Master's thesis, (2010)

[26] J. U. Kim, C. J. Park, The effect of a character development program on self-esteem and school adjustment of multicultural families children, Journal of North-east Asian Cultures, (2011), No.27, pp.41-59, DOI: $\quad 10.17949 /$ jneac.1.27.201106.003

[27] H. S. Kim, Development of group counseling program for the ability of interpersonal relation of multicultural students of the higher grades of elementary school, Korea National University of Education, Master's thesis, (2014)

[28] C. D. Kim, Development and evaluation of counseling and psychological education programs, Hakjisa, (2011)

[29] P. J. Lee, The development of a group counseling program using character strength cards to improve peer relationships of multicultural elementary school students in upper grades, Korea National University of Education, Master's thesis, (2018)

[30] B. H. Kawk, The development of group counseling program to improve ethnic identity of children from muticutural family, Korea National University of Education, Master's thesis, (2012) 
[31] G. S. Choi, The effects of positive psychology coaching program on self-efficacy, attitude of a class, comradeship for multicultural family' children, Kwangwoon University, Master's thesis, (2013)

[32] M. S. Kim, The effects of self-esteem program on self-esteem and school adjustment of multicultural families children, Sookmyung Women's University, Master's thesis, (2009)

[33] T. M. Jung, The effects of music therapy activities on their sociality and self-esteem of children from multi-cultural families, Hansei University, Master's thesis, (2010)

[34] C. Y. Kim, Effects of group art therapy on emotional purification and self-esteem Enhancement of multicultural families children, Gwangju National University of Education, Master's thesis, (2014)

[35] S. A. Jung, J, Y. Yang, E. S. Choi, The effect of emotional and social-skill improvement program on self-esteem, peer relational skill and emotional-behavioral problems for multi-cultural children, The Journal of Play Therapy, (2014), Vol.18, No.3, pp.49-67, UCI: G704-001383.2014.18.3.005

[36] M. S. Kwak, Reading instruction program with picture books on the self-esteem and readingattitude of children from multicultural families, Catholic University of Korea, Master's thesis, (2015)

[37] B. G. Choi, G. Y. Jeon, Research : A Study on the Development of $\ulcorner$ the Self - Esteem Inventory $\lrcorner$ (1), Family and Environment Research, (1993), Vol.31, No.2, pp.41-54.

[38] S. Coopersmith, The antecedents of self-esteem, W. H. Freeman, (1967)

[39] J. H. Kim, Elementary school teacher group counseling manual to help children's family relationships, Ewha Education Series, (2003)

[40] S. Y. Son, R. Lee, A living story of multicultural education, Happy School, (2013)

[41] H. J. Shin, The influence of parent-child relationship and multicultural identity on self-esteem and adaptation to Korean life in children and adolescents of multicultural families, Asia-pacific Journal of Multimedia Services Convergent with Art, Humanities, and Sociology, (2019), Vol.9, No.4, pp.597-604, DOI: 10.35873/ajmahs.2019.9.4.057

[42] M. J. Yang, D. H. Lee, H. Y. Gao, Y. H. Kim, H. J. Nam, A qualitative study on perception of helping professionals working for the culturally diverse adolescents, Korea Journal of Counseling, (2012), Vol.13, No.3, pp.1181-1209, DOI: 10.15703/kjc.13.3.201206.1181

[43] J. J. Jeong, Instructional methods and program design aimed at promoting self-esteem for personality development, The Korean Journal of Elementary Counseling, (2016), Vol.1, pp.537-561, UCI: G704-SER000003102.2016...006 